\title{
Q methodology and the measurement of subjectivity in corporate brand perception
}

\author{
G. Angelopulo* \\ CENTRUM Católica, Pontificia Universidad Católica del Perú, Calle Alomía Robles 125 - 129, \\ Urb. Los Alamos de Monterrico, Surco, Lima 33, Perú \\ gangelopulo@pucp.edu.pe
}

Received July 2009

\begin{abstract}
This paper reviews Q methodology and its application in an area of business research in which subjectivity is of considerable importance - that of corporate brand perception. More specifically, it explores the dimension of corporate brand perception that is directly related to the consumption and utilisation of the brand. The consumption-specific dimension of corporate brand perception is conceptualised as the 'solution meaning of the corporate brand', and the process of identifying the solution meaning with the aid of Q methodology is described and applied in a case study.
\end{abstract}

*To whom all correspondence should be addressed.

\section{Introduction}

Q methodology was initially developed in 1935 in order to identify the subjective opinions that exist on defined topics amongst specified individuals or groups. It has been used continuously from that time but despite its promise, cannot be considered a mainstream research methodology. This paper reviews Q methodology and its application in an area of business research in which subjectivity is of considerable importance - that of corporate brand perception. More specifically, it explores the dimension of corporate brand perception that is directly related to the consumption and utilisation of the brand. The consumption-specific dimension of corporate brand perception is conceptualised as the 'solution meaning of the corporate brand', and the process of identifying the solution meaning with the aid of Q methodology is described and applied in a case study.

\section{Q methodology}

Q methodology has its origins in the work of William Stephenson (1935a; 1935b), a student of Charles Spearman, the founder of factor analysis. Working primarily in psychology, Stephenson's intention was to develop factor analysis in ways that would make it suitable for inductive research, as opposed to the deductive applications for which it had almost entirely been utilised at the time. Stephenson wrote that "modern science has prospered by eliminating whims and arbitrary subjectivities from its fact-finding missions into the world 'outside.' $\mathrm{Q}$ methodology follows the same prescriptions for what we consider 'inside' us, matters of mind, consciousness, wishes and emotions... What is involved is the discovery of hypotheses and reaching understandings, instead of testing hypotheses" (Brown, 1980: x). Whereas factor analysis had most commonly been used to factor (or classify) variables or traits, Stephenson used it to classify respondents according to similarities in their opinions on particular topics. His objective was to identify the span and variations of subjective opinion evident within a specific group of individuals on a particular topic.

Q methodology was primarily used in psychology until the 1970's for single studies into the subjectivity of a range of topics, and as a means of standardised measurement in, for example, personality assessment and psychotherapeutic counselling (McKeown \& Thomas, 1988). From the 1970's onwards it became more widely used in other disciplines, for example in politics (Brown, 1980), resource management (Steelman \& Maguire, 1999) and education (Cross, 2005). Q methodology has also been used in business research to investigate, for example, consumer behaviour and segmentation (Albanese, 1993; Martin \& Reynolds, 1976), quality programme implementation (Wright, Riggle \& Wright, 1998), strategic planning (Popovich \& Popovich, 2000), public relations orientation (Black \& Härtel, 2002), material possession attachment (Kleine \& Baker, 2004), customer loyalty (Rosenbaum, Ostrom \& Kuntze, 2005) and organisational culture (Zsóka, 2007).

The principles, processes and statistics that form the foundation of Q methodology have always been accessible, for example in Stephenson (1953) and Brown (1980), but it is only with the more recent availability of software suitable for Q studies that its use has increased. Despite the relative increase in the use of $\mathrm{Q}$ methodology in the past two decades, it cannot be considered a mainstream methodology. With some exceptions Q methodology is unknown in many academic institutions, it is rarely considered as an alternative in market research, and most widely used statistical packages such as SAS or SPSS make no specific provision 
for the methodology. Nonetheless, Q methodology is a particularly promising research alternative where questions of subjectivity arise, as much in economic, management and marketing research as in psychology, where it was initially developed and applied.

\section{The unique aspects of $Q$ methodology}

Q methodology measures subjectivity, not empirical fact (Stephenson, 1953). It has proved to be most useful in studies that are undertaken to identify the range of communicated ideas in a particular discourse, the prevalent variations within the discourse, the logical relationship between these variations, and the nature of the subjective understandings that exist in the discourse from the perspective of the people participating in it; it is less suitable for the identification of truth in a discourse or the traits of the people participating in it (Brown, 1996; Cross, 2005; Kitzinger, 1987; Stainton Rogers, 1995; Stricklin \& Almeida, 2004). Q methodology is fundamentally qualitative, although it may more accurately be described as "qualiquantological" as it is a qualitative methodology with strong quantitative features (Watts \& Stenner, 2005: 69). Brown (1996) believes that $Q$ methodology bridges qualitative and quantitative research, with advantages of both. "The qualitative nature of the methodology is due to the fact that it requires neither a certain sample size as precondition for reliable quantitative analysis, nor representativeness... [and]... by generating typical opinions assists... in shape recognition” (Zsóka, 2007: 115). Q methodology's primary differentiators are in part statistical and in part procedural.

Q methodology correlates people as opposed to traits, while factor analysis more commonly measures traits and the differences between traits against a sample of a population of people (Brown, 1980). The " $Q$ methodology approach to participants may seem perverse. They are not sampled... rather they are chosen to facilitate the expectation of finite diversity” (Stainton Rogers, 1995: 182). The aim is to identify the 'finite diversity' that exists in the discourse under consideration, not to identify characteristics of the population from which the sample is drawn. Participants are therefore selected for their potential to contribute meaningfully to the expression of the full but finite diversity of that discourse. In practice participants may therefore be selected according to the researcher's judgement, through strategic sampling, or through disproportional stratified sampling, to ensure the identification of majority and minority views (Schmolck, 2008; Stainton Rogers, 1995). In the case of Q methodology, sampling, as it is normally understood, is not applied to the population from which the participants are drawn, but rather to the range of elements that make up the broader discourse under consideration, in order to ensure that the items presented to the participants for assessment are representative of the full discourse (Brown, 1980; Stainton Rogers, 1995).

In the typical data matrix for factor analytical calculations, columns represent traits, rows represent the sample of individuals, and the data represent the values or scores of each individual on the particular trait, given in the unit of measurement of the trait. The unit of measurement of a particular trait may differ from column to column. Q methodology inverts this methodology, measuring people against a sample of traits. In such studies the correlation of data is logical only where the units being measured are the same in both columns and rows (Brown, 1980: 13), but a problem exists in that the traits against which the individuals are measured may often be measured in different units (e.g. for length and weight). "In terms of the normalization subsumed in correlation, therefore - i.e., given that each row is to be centred by computing deviation scores around the row mean - what possible meaning can be attributed to an average score that is a composite of diverse measuring units?” (Brown, 1980: 15). Stephenson (1953) provides comparability of such diverse units of measurement by specifying their assessment not in terms of objective criteria, but rather in terms of subjective criteria such as likability or perceived significance.

Q methodology is further characterised by its utilisation of centroid factor extraction and the allowance made for judgemental factor rotation. Centroid analysis was initially used in factor analysis for its relative simplicity in application without machine assistance. Because of its indeterminacy, however, centroid analysis is now scarcely used outside of $\mathrm{Q}$ methodology, having been replaced by mathematically more exact alternatives such as varimax or quartimax. In Q methodology, however, centroid analysis is retained precisely because of its indeterminacy (Brown, 1980; Stricklin \& Almeida, 2004). Judgemental rotation, which permits an infinite number of solutions that are based on the theoretical perspective of the researcher, is also utilised because of this indeterminacy (Brown, 1980). In practice, varimax rotation is preferable if the objective is the mathematical derivation of factors, and judgemental rotation is preferable if factors are to be generated according to the researcher's specific theoretical objectives.

\section{The research process - identifying the solution meaning of a corporate brand}

As a procedure, $\mathrm{Q}$ methodology typically follows a specific sequence: the researcher identifies and collects the concourse; selects the Q and person samples; organises the assessment and ranking of the $\mathrm{Q}$ sample by participants; captures, processes and analyses the data; and finally interprets the results (du Plessis, Angelopulo \& du Plessis, 2006; Stricklin \& Almeida, 2004). In the case discussed in this article, the procedure is used to identify the subjective perceptions that determine utilisation or rejection of the corporate brand of a company involved in the financing of industrial research. The company had experienced high staff turnover, static demand and a degree of client dissatisfaction. The study was undertaken to establish the main perceptions that contribute to its use or rejection by its market of researchers and other decision makers in research institutions and industrial companies.

\section{The concourse}

Following Brown (1980) and Cross (2005), the first step in $\mathrm{Q}$ methodology is to identify the broad spectrum of communicated ideas on the topic under investigation. This discourse is termed the 'concourse' in Q methodology. 
The concourse can be derived in many ways, and for the purpose of this study the selected concourse was that which has been theoretically circumscribed in Grönroos (2007) and related literature on the factors determining the utilisation and consumption of the corporate brand, its products and services.

The overall corporate brand concept is not used as the theoretical frame for the concourse because it is too broad and insufficiently specific for the scope of the enquiry, signifying as it does more than consumption-related aspects of brand perception. 'Brand' lacks specificity because it is often used synonymously with commodity, reference, icon, company, policy, physique, personality, culture, relationship, reflection or self-image (Kapferer, 1997; McEnally \& de Chernatony, 1999). Related concepts such as brand image, corporate image or corporate brand image are also too broad for the specification of the concourse. While they do refer to perception of the corporate entity from the perspective of external stakeholders in general and the customer in particular (Bernstein, 1986; Davies, Chun, da Silva \& Roper, 2001; Kapferer, 1997), they also overlap extensively with related concepts such as corporate culture, identity and reputation (Kennedy, 1977; Schultz \& Ervolder, 1998; Wei, 2002), and do not adequately address the question of consumption or usage.

The literature on the assessment of brands is extensive, as are models for such assessment. Most models focus on aspects of the corporate brand other than its subjectivity or generalised perceptual foundations. See, for example Keller, 2001; Keller, 2003; Kuhn, Alpert and Pope, 2008; the UCAV model of Spears, Brown and Dacin (2006); the internal marketing perspective of Papasolomou and Vrontis (2006); or the corporate brand association approach of Uggla (2006).

The scope of the concourse is more rigorously framed by a theoretical framework suggested by Grönroos (2007), whose contention it is that the brand gains significance in the market only as the brand image that exists in the mind of the customer and in the brand relationship that results from that image. As intended by the company - as brand identity - the brand remains provisional until it is conceptualised and acted upon by the customer in a way that coincides with the company's intention. It is the customer who creates value, not the company (Crosby, Grönroos \& Johnson, 2002), and this value is manifested through consumption.

Consumption ensues if the customer believes that the brand offers the best solution to a specific need while simultaneously contributing to his or her own value-creating processes. Such beliefs result from the expectation or experience that the brand will relieve or enable the customer, reduce costs, or increase performance (Porter, 1985; Ravald \& Grönroos, 1996). These perceptions of positive differentiation and value creation contribute directly to consumption of the brand and may in combination be termed the 'solution meaning' of a brand, following Grönroos' (2007: 331) more general use of the term to refer to the quality of the relationship that a customer perceives to exist between him- or herself, and specific goods or services.
Solution meaning originates in perceptions that are generated from diverse sources. Moriarty (Harris, 1998: 293) observes that the brain "gathers information from an untold number of contact points and assimilates it into one picture”. In relation to brands, these contact points include planned, product, service and unplanned message sources (Duncan \& Moriarty, 1997). Grönroos (2000; 2007) reviews these sources of brand meaning and how they affect perception of the relative advantage of particular corporate brands.

A dominant reason for the consumption of a brand is perception of the relative advantage of its core solution, but this occurs only where such advantage is evident (Grönroos, 2007). Increasingly, relative advantage is not evident in companies' core solutions. Consumption of a brand may also be structurally determined by market factors such as prevailing economic conditions, seller concentration, competition, dominance or size (Porter, 1980; Scherer, 1980), and competition may be limited by cost of entry or legislation. Brand consumption may be driven by the variables identified in the marketing mix, be they in the form originally proposed by Borden (1964), as the Four P's of McCarthy (1960) or the multiple P's of others (Diamond \& Oppenheim, 2004). With the possible exception of structural determinants and price, however, it is questionable that these variables explain the consumption of corporate brands to the same degree that they explain the consumption of packaged goods (Grönroos, 1997).

Service quality and service relationships play an increasingly significant role in the success of companies and their corporate brands. Service has increased in importance because the comparative advantage of other variables has diminished. There is an abundance of products with little tangible difference between them, product innovation can easily and cheaply be copied, little difference is evident in the quality of products within similar price bands, and a move from a product to a service base can be noted in most economies (Duncan, 2002). Service quality is crucial to organizations' performance and success (Buzzell \& Gale, 1987; Parasuraman, Berry \& Zeithaml, 1991) and currently the most powerful competitive trend determining strategy in business and marketing (Abdullah, 2006). Grönroos (2007) suggests that most companies are service businesses because their core offerings are rarely a guarantee of competitive advantage, and they rely increasingly on service to establish such advantage.

Service quality has a number of dimensions. It has a technical dimension that refers to outcome quality, the perceived quality of the solution that the customer retains at the conclusion of the buyer-seller interaction, and which can be conceptualised as 'what' the customer obtains (Caceres \& Paparoidamis, 2007). The perception of service quality also has a functional dimension that refers to process quality, the perceived quality of the entire process of obtaining the technical solution, which can be conceptualised as 'how' the customer obtains the solution (Caceres \& Paparoidamis, 2007). The overall perception of service quality is also influenced by "image-filter" (Grönroos, 2000), a perceptual filter that positively or negatively affects overall quality perception and which, in 
turn, is affected by perceptions of technical and functional quality (Caceres \& Paparoidamis, 2007).

At a more fundamental level a wider range of variables have been identified as determinants of service quality including, among others, reliability, responsiveness, assurance, empathy, tangibles, access, location, servicescape, friendliness, waiting times, convenience, relatedness and availability (Bitner, 1992; Bojanic \& Rosen, 1994; Brady \& Cronin, 2001; Law, Hui \& Zhao, 2004; Lee \& Ulgado, 1997; Zeithaml, Berry \& Parasuraman, 1988). These and similar variables have been proposed as criteria of both service quality and corporate image, and they have been extensively interrogated in the literature with varying degrees of substantiation (Andreassen \& Lanseng, 1997; Carman, 1990; Cronin \& Taylor, 1992; Hsieh, Chou \& Chen, 2002; LeBlanc \& Nguyen, 1998). Grönroos (2007) has consolidated those that he sees as the most significant with the technical, image and functional categories of service quality. Professionalism and skills are defined as the technical dimensions of quality; reputation and credibility as its image-filter dimensions; and attitudes, behaviour, accessibility, flexibility, reliability, trustworthiness, service recovery (the ability to recover from service problems) and servicescape (the environment in which the service is offered and consumed) as the functional dimensions of quality.
In summation, therefore, the solution meaning of a corporate brand is determined in character and degree by seven clusters (or categories) of variables, and these in turn form the span of the concourse. The clusters are the perception of professionalism and skills (technical quality); attitudes and behaviour (process quality); accessibility and flexibility (process quality); reliability, trustworthiness and service recovery (process quality); servicescape (process quality); reputation, credibility and image (image-filter); core solution, market structure and marketing mix (marketspecific variables).

\section{Selection of the Q sample}

Once the concourse has been identified, a sample of items is drawn from it to create the ' $Q$ sample', a smaller, representative and more manageable list of items. In this study, where the concourse is governed by categories or subcategories, theoretical modelling is used to structure the Q sample (Brown, 1980). While Q samples range widely in number, 40 to 75 items have been identified as a preferable $\mathrm{Q}$ sample size (Cross, 2005). The $\mathrm{Q}$ sample for this study comprises 49 items. Its theoretical structure is illustrated in Table 1.

Table 1: Theoretical structure of the $Q$ sample

\begin{tabular}{|c|c|c|c|c|c|c|}
\hline$\frac{7 \text { items }}{\text { related to: }}$ & $\frac{7 \text { items }}{\text { related to: }}$ & $\frac{7 \text { items }}{\text { related to: }}$ & $\frac{7 \text { items }}{\text { related to: }}$ & $\frac{7 \text { items }}{\text { related to: }}$ & $\frac{7 \text { items }}{\text { related to: }}$ & $\frac{7 \text { items }}{\text { related to: }}$ \\
\hline Professionalism & Attitudes & Accessibility & Reliability & Servicescape & Reputation & Core solution \\
\hline Skills & Behaviour & Flexibility & $\begin{array}{l}\text { Trustworthiness } \\
\text { Service } \\
\text { recovery }\end{array}$ & & $\begin{array}{l}\text { Credibility } \\
\text { Image }\end{array}$ & $\begin{array}{l}\text { Market } \\
\text { structure } \\
\text { Marketing mix }\end{array}$ \\
\hline
\end{tabular}

In this study items were selected for diversity within their theoretical categories, drawn up and adapted to the unique conditions of the institution, its industry and the broader market, and finally formulated as statements that related directly to the company. In order to "avoid confounding the measure of the attitude itself with acquiescent response style" (Kidder \& Judd, 1986: 204), statements within categories were roughly divided between those formulated in the positive and those in the negative. Items were finally approved and signed off by the company.

The items of the $\mathrm{Q}$ sample constitute within them significance at two levels: at the level of the overt statement and at the level of its theoretical category. Figure 1 indicates, as an example, the composite levels of one statement. Every item was constructed in a similar way.

Table 2 lists the Q sample - the set of statements used in the study.

Once selected, the 49 items of the Q sample were printed onto numbered cards, one statement per card, making up a 49-card deck that was ready for assessment by the participants in the study. 


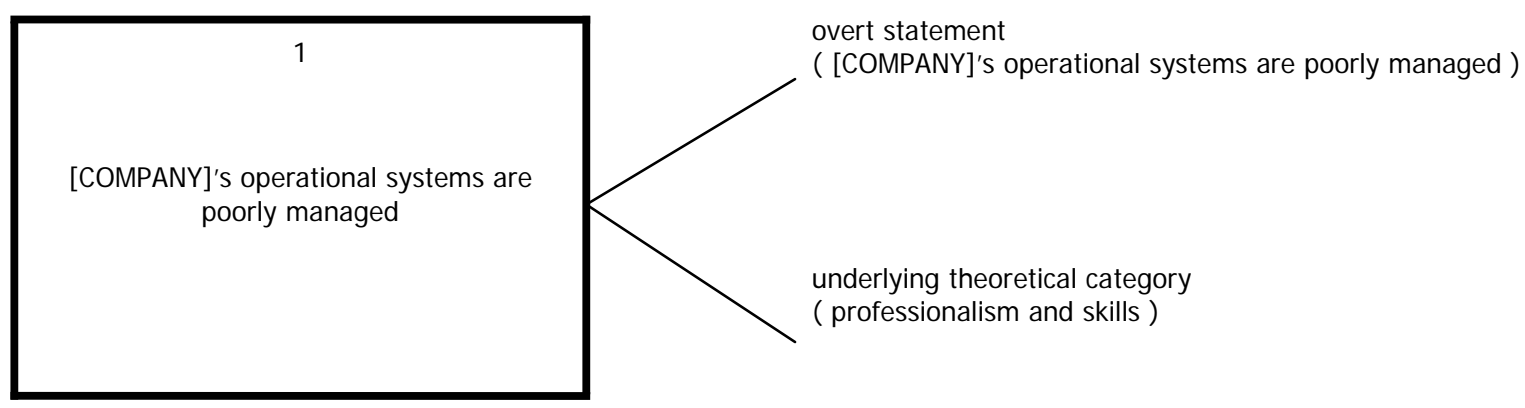

Figure 1: An example of the theoretical levels of an item in the $Q$ sample

Table 2: The $\mathbf{Q}$ sample

\begin{tabular}{|c|c|c|c|c|c|c|c|c|}
\hline \multirow[t]{2}{*}{ no } & \multirow[t]{2}{*}{ items } & \multicolumn{7}{|c|}{ theoretical categories } \\
\hline & & 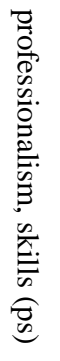 & 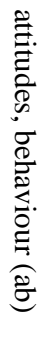 & 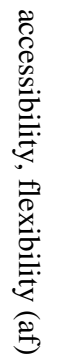 & 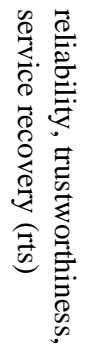 & 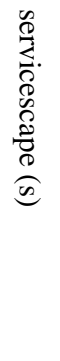 & 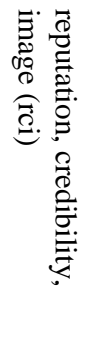 & 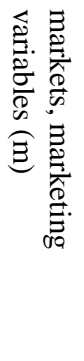 \\
\hline 1 & [COMPANY]'s operational systems are poorly managed & ps & & & & & & \\
\hline 2 & $\begin{array}{l}\text { [COMPANY] significantly improves the commercial exploitation of science } \\
\text { and technology }\end{array}$ & ps & & & & & & \\
\hline 3 & $\begin{array}{l}\text { [COMPANY] does not have the staff resources to significantly improve } \\
\text { industrial competitiveness }\end{array}$ & ps & & & & & & \\
\hline 4 & $\begin{array}{l}\text { [COMPANY]'s personnel have a clear understanding of the needs of their } \\
\text { clients }\end{array}$ & ps & & & & & & \\
\hline 5 & [COMPANY] is a well-run institution & ps & & & & & & \\
\hline 6 & [COMPANY] gives good guidance to clients throughout the service process & ps & & & & & & \\
\hline 7 & Clients’ financial risks are not properly managed by [COMPANY] & ps & & & & & & \\
\hline 8 & [COMPANY] employees are uninterested in solving clients' problems & & $\mathrm{ab}$ & & & & & \\
\hline 9 & The quality of [COMPANY]'s responses to enquiries is poor & & $\mathrm{ab}$ & & & & & \\
\hline 10 & [COMPANY] employees recognise clients’ needs quickly & & $\mathrm{ab}$ & & & & & \\
\hline 11 & $\begin{array}{l}\text { [COMPANY] employees are strongly motivated to help clients obtain finance } \\
\text { for their research }\end{array}$ & & ab & & & & & \\
\hline 12 & [COMPANY]'s response to enquiries is slow & & $\mathrm{ab}$ & & & & & \\
\hline 13 & [COMPANY] clearly explains its service processes to clients & & $\mathrm{ab}$ & & & & & \\
\hline 14 & [COMPANY] employees are not motivated to serve clients & & $\mathrm{ab}$ & & & & & \\
\hline 15 & Access to [COMPANY] employees is good & & & af & & & & \\
\hline 16 & [COMPANY] has unsatisfactory schedules \& timetables & & & af & & & & \\
\hline 17 & $\begin{array}{l}\text { Programme participants find [COMPANY]'s operational systems difficult to } \\
\text { use }\end{array}$ & & & af & & & & \\
\hline 18 & [COMPANY] offers good service by phone & & & af & & & & \\
\hline 19 & Clients wait too long for the service they require from [COMPANY] & & & af & & & & \\
\hline 20 & [COMPANY] is prepared to adjust to the needs of its clients & & & af & & & & \\
\hline 21 & [COMPANY]'s online services are good & & & af & & & & \\
\hline 22 & [COMPANY] performs inconsistently & & & & rts & & & \\
\hline 23 & [COMPANY] delivers what it promises & & & & rts & & & \\
\hline 24 & Parts of [COMPANY] perform notably better than others & & & & rts & & & \\
\hline 25 & [COMPANY] always acts in clients' best interest & & & & rts & & & \\
\hline 26 & [COMPANY] deals promptly with problems when they arise & & & & rts & & & \\
\hline
\end{tabular}




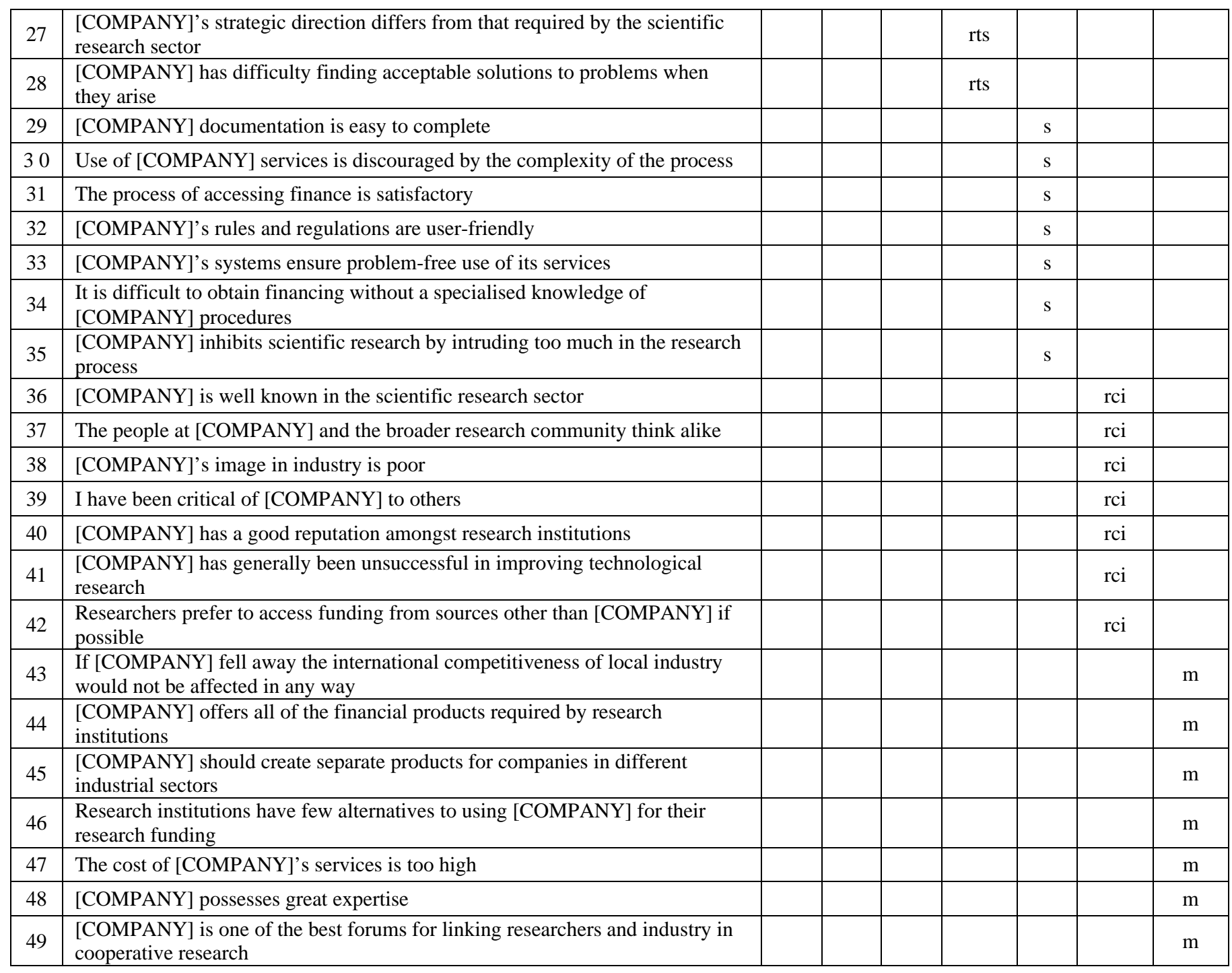

\section{Table 3: Person sample structure}

\begin{tabular}{c|l}
\hline \multirow{4}{*}{$\begin{array}{c}\text { } \text { 'internal' } \\
\text { participants }\end{array}$} & shareholding companies \\
\cline { 2 - 2 } & management \\
\cline { 2 - 2 } & customer facing employees \\
\cline { 2 - 2 } 'external' & support function employees \\
\cline { 2 - 2 } participants & current individual researcher clients \\
\cline { 2 - 2 } & lapsed \& potential individual researcher clients \\
\cline { 2 - 2 } & specialized research institutions \\
\hline
\end{tabular}

\section{Selection of the person sample}

The participants in a Q study are named the "person sample" or "P set" (Brown, 1980; Steelman \& Maguire, 1999). Participants in this study were selected in order to reflect the widest range of opinions on the discourse (Du Plessis et al., 2006), and in order to do this, a group wider than the company's customer base was sought. The customer creates value, not the company, but the creation of value is not a function of the customer-company relationship only. It is also a function of the relationships that predetermine it those existing between customer, company, and all other significant stakeholders (Balmer \& Greyser, 2006; McDonald, de Chernatony \& Harris, 2001). Understanding the relationships between customer and brand requires an understanding of the relationships between all significant stakeholders and the brand. Such understandings make it possible to focus on activities and processes that contribute directly to consumption and to avoid those that do not. For these reasons a person sample of 80 was selected to include the views of all significant stakeholders, internal and external.

'Internal' participants were drawn from the company's shareholders, management, customer facing and support function employees. 'External' participants were drawn from amongst current, lapsed and potential individual researcher clients, specialised research institutions, and commercial companies engaged in research.

\section{Assessment and ranking of the $Q$ sample by participants}

In Q methodology data is most commonly collected in a 'Qsort' process in which participants arrange the deck of cards on a forced-choice response grid according to specific conditions of instruction. One block is made available per item, and at the end of the assessment there must be one card in each of the available blocks. Participants in this study were requested to place each item onto the grid 
according to the degree to which they agreed that it represents a reason for the research industry's utilisation of the company's services. Figure 2 illustrates the forcedchoice response format used in the study. The advantage of this format is that it simultaneously permits the arrangement of items according to their significance on the assessment scale, and according to their significance relative to each other. It also forces the identification of smaller numbers of more significant items by ranging these at the extremes of the response format ( -5 for items most disagreed with and 5 for items most agreed with).

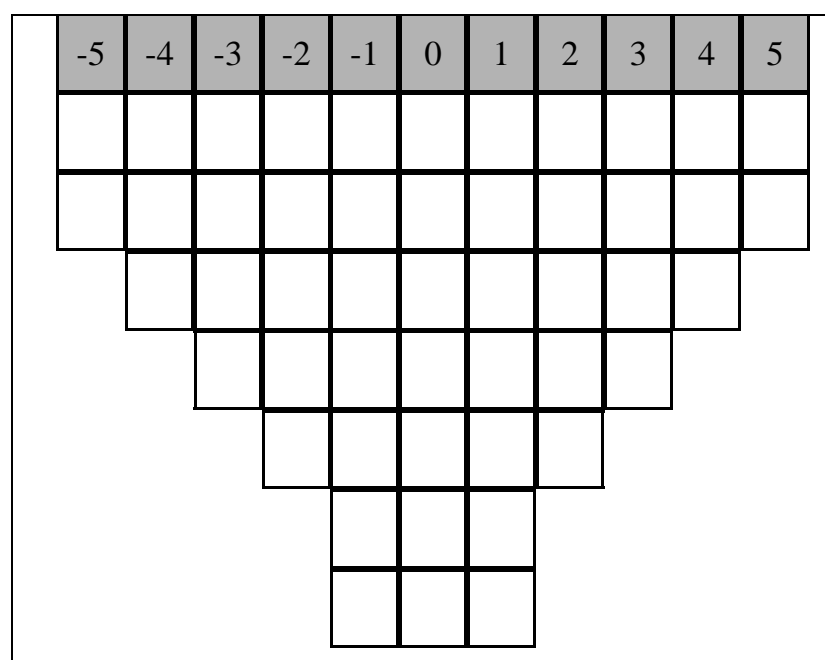

Figure 2: The response grid

\section{Data capture and processing}

Data was recorded in the field by noting each participant's item placement on the grid by number. Participants were further encouraged to discuss their item rankings and their views on any of the items. These discussions were recorded and transcribed for later interpretation and additional insight into the findings of the study.

Data processing can be undertaken with software specific to the methodology such as PCQ for Windows or PQMethod, but more commonly available statistical packages may also be adapted for the purpose. PCQ was used in this study. A correlation matrix of the $\mathrm{Q}$ sorts was generated and a centroid factor analysis performed. The derived centroids were then subjected to Varimax rotation for the mathematical derivation of factors. Judgemental rotation was not utilised as the objective was not the generation of factors according to specific theoretical objectives. Factors with an eigenvalue of 1.0 or more were selected, and in this way six factors were derived.

Each derived factor was visually represented in the form of a completed Q sort. An example is given in Figure 3. The numbers within the body of the sort represent their corresponding statements in the Q sample.

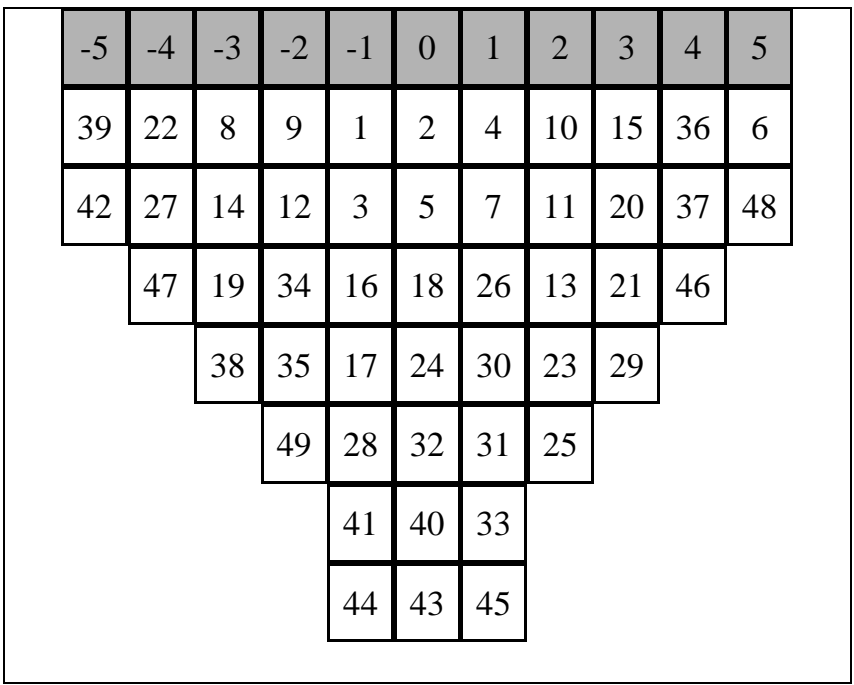

Figure 3: The visual presentation of individual factors

\section{Analysis and interpretation}

The six derived factors accounted for 51 percent of the variance. 47 of the 80 participant sorts were accounted for in these six factors. Of the remaining participant sorts, 25 were confounded - they registered on more than one factor; and eight were insignificant - they did not load sufficiently on any factor. Significance was determined by factor loadings (the extent to which an individual sort correlates with the factor, with decimals of two places omitted) of 37 or more.

The derived factors were separately assessed, interpreted and named. The analysis was undertaken at the level of the overt statements and at the level of the underlying theoretical categories. For the latter, values were adjusted to compensate for the larger number of items within the process quality item clusters. Finally, names were selected for the factors that described their core characteristics.

\section{Factor 1: Successful financial service}

Factor 1, with 22 percent of the total variance and an eigenvalue of 17,83, represents the single strongest perception of the corporate brand and the reasons for its use in the market. Titled Successful Financial Service, it reflects an exceptionally positive view of the company. Perceptions include good service management; satisfactory products and services; effective operation; meeting market needs; and the belief that the company plays an essential role in the advancement of technological research within its market. Employees are seen to be dedicated in solving clients' problems when these arise, they give good guidance to clients throughout the service process, and the company is seen as one of the best forums for linking researchers and industry in cooperative research.

Figure 4 indicates the factor's weighting on the underlying drivers of consumption of the company, its products and services. Brand consumption is driven by all underlying variables - all have positive values - with the most important being employees' attitudes and behaviour, followed by the company's reputation, credibility and image, marketing, and market structure. 


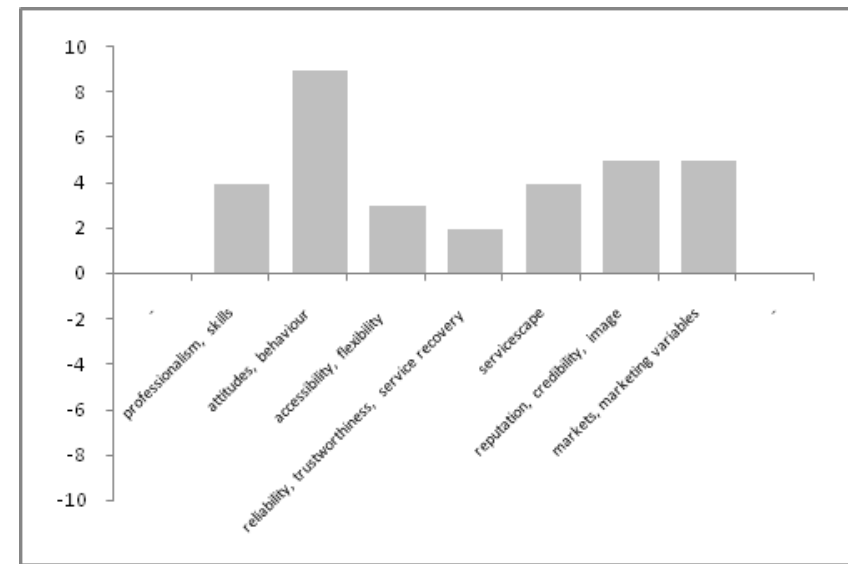

Figure 4: The underlying drivers of consumption in Factor 1

Table 4 indicates that Factor 1 is evident in all categories of the person sample.

Table 4: Participants loading on Factor 1

\begin{tabular}{l|c}
\hline shareholding companies & $\mathrm{X}$ \\
\hline management & $\mathrm{X}$ \\
\hline customer facing employees & $\mathrm{X}$ \\
\hline support function employees & $\mathrm{X}$ \\
\hline current individual researcher clients & $\mathrm{X}$ \\
\hline lapsed \& potential individual researcher clients & $\mathrm{X}$ \\
\hline specialized research institutions & $\mathrm{X}$ \\
\hline commercial companies engaged in research & $\mathrm{X}$ \\
\hline
\end{tabular}

\section{Factor 2: Poor systems implementation}

Factor 2, with 11 percent of the variance and an eigenvalue of 8,61, is titled Poor Systems Implementation. Participants holding this view have positive and negative views of the company and the value that it offers them. The company's contribution to the research industry and its ability to link researchers and industry in cooperative research are seen as its most positive attributes, but these factors are not perceived to be strong enough to drive use of the company. More significantly, clients are perceived to reject the company for a number of specific reasons that include difficulty in navigating the company's systems, particularly its online systems; the incidence of service problems that remain unresolved; and application and processing systems that are complex, tedious and inefficient.

Factor 2's weightings on the underlying drivers of consumption are all negative. Participants holding this view avoid the company, its services and products. Most negative is their view of the company's servicescape - the environment in which its service is offered, and poor perceptions of reputation, credibility, image, reliability, trustworthiness and the company's ability to recover from service problems.

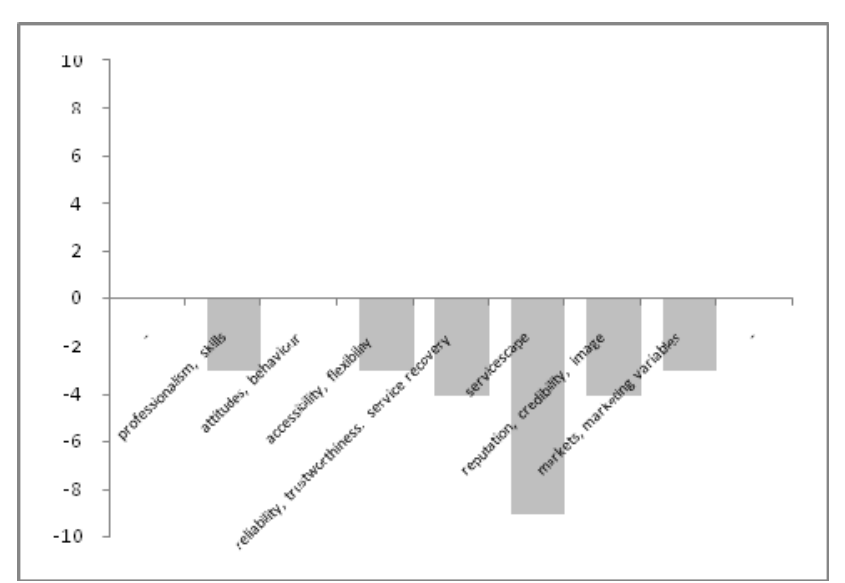

Figure 5: The underlying drivers of consumption in Factor 2

This factor represents the views of a number of participants from 3 of the 4 client categories and in the client-facing employee category of the person sample. It indicates that amongst certain client categories the company is avoided as a source of research finance, and that this perception is reflected amongst some of the employees that interact with clients, but no one else in the company.

Table 5: Participants loading on Factor 2

\begin{tabular}{l|c}
\hline shareholding companies & \\
\hline management & \\
\hline customer facing employees & $\mathrm{X}$ \\
\hline support function employees & \\
\hline clients, current - individual researchers & $\mathrm{X}$ \\
\hline clients, lapsed \& potential - individual researchers & $\mathrm{X}$ \\
\hline specialized research institutions & $\mathrm{X}$ \\
\hline commercial companies engaged in research & \\
\hline
\end{tabular}

\section{Factor 3: Good company}

Factor 3, termed Good Company, represents a very positive view of the company. It accounts for 6 percent of the variance and an eigenvalue of 4,93. The factor itself reflects exceptionally negative views of the company, but on inspection it is evident that the factor is bipolar - only 1 of the five sorts that load on the factor is positive (in agreement). The remainder load negatively, indicating that views held are the exact opposite of those represented by the factor. The company is, therefore, perceived to contribute significantly to the commercial exploitation of science and technology; it is believed to be well known in the market; its intrusion into the research that it finances is minimal; and its contribution to the international competitiveness of local industry is positive.

All underlying drivers of consumption are positive. The most positive is servicescape, and the company is perceived to offer good value within a competitive market, with its marketing perceived to be very good. 


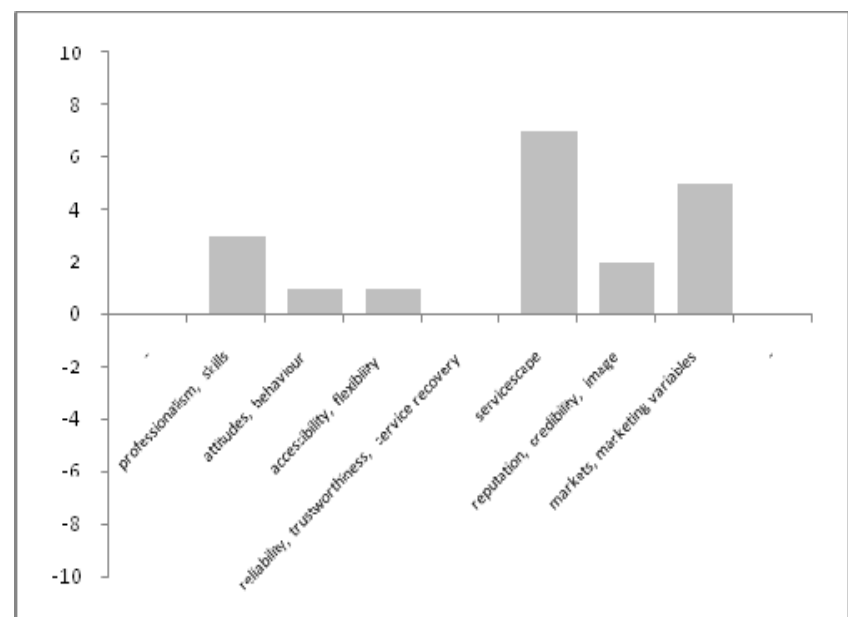

Figure 6: The underlying drivers of consumption in Factor 3

Factor 3 is evident amongst some clients in three of the four client categories.

\section{Table 6: Participants loading on Factor 3}

\begin{tabular}{l|c}
\hline shareholding companies & \\
\hline management & \\
\hline customer facing employees & \\
\hline support function employees & $\mathrm{X}$ \\
\hline current individual researcher clients & $\mathrm{X}$ \\
\hline lapsed \& potential individual researcher clients & \\
\hline specialized research institutions & $\mathrm{X}$ \\
\hline commercial companies engaged in research
\end{tabular}

The one sort that loads positively on this factor has the highest loading $(0,61)$. The view that it represents is negative on all of the factors noted above as positive. The participant holding this view is an individual researcher in the lapsed client group.

\section{Factor 4: Good strategy, poor implementation}

Factor 4, with 4 percent of the variance and eigens of 3,21 is termed Good Strategy, Poor Implementation. The factor represents a mixed but generally negative view of the company's market appeal. Its strategic direction is seen to be satisfactory but its products and processes are not. The company is not perceived to be sufficiently well known and it has a poor image, while its primary value offering access to research finance - is also seen to be weak. Its strategic direction, however, is seen to coincide with that required by the technology sector.

While none of the underlying drivers of consumption register particularly strongly, the company's servicescape, accessibility and flexibility are seen as its most negative attributes; professionalism and skills are seen as its most positive.

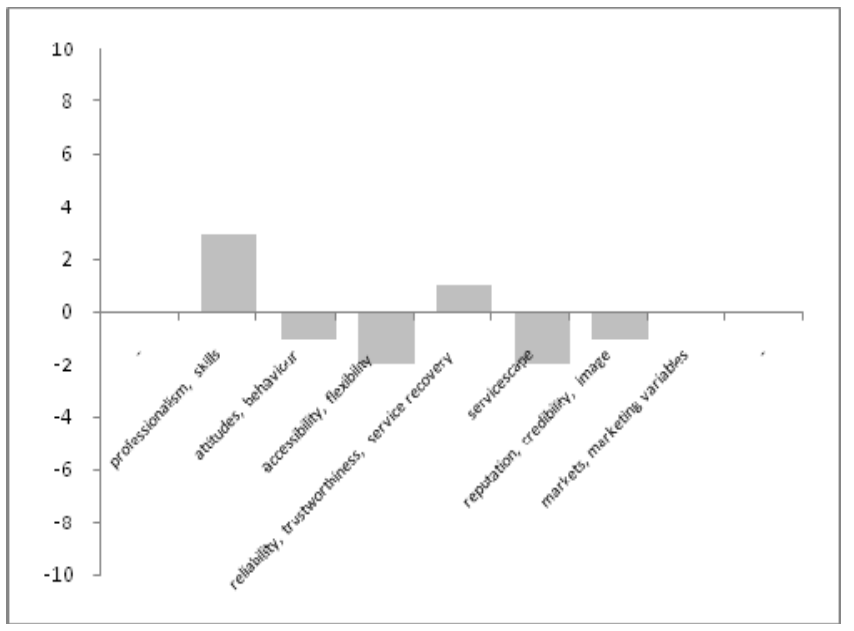

Figure 7: The underlying drivers of consumption in Factor 4

Factor 4 is only evident amongst clients. This factor is also bipolar, with a minority view of one client participant identified as holding the opposite of the perceptions described by the factor here.

\section{Table 7: Participants loading on Factor 4}

\begin{tabular}{l|c}
\hline shareholding companies & \\
\hline management & \\
\hline customer facing employees & \\
\hline support function employees & $\mathrm{X}$ \\
\hline current individual researcher clients & \\
\hline lapsed \& potential individual researcher clients & \\
\hline specialized research institutions & $\mathrm{X}$ \\
\hline commercial companies engaged in research
\end{tabular}

Factor 5: Good employee attitude but avoid the company

Factor 5 is termed Good Employee Attitude But Avoid The Company. It has an eigenvalue of 4,28 and accounts for 5 percent of the variance. The company is perceived to have a poor reputation, a negative image and fundamentally poor systems. On the other hand it is perceived to contribute to the international competitiveness of local industry and to offer the product diversity required by different research sectors. The major advantage identified by participants who hold this view is the positive attitude of employees.

The underlying drivers of consumption in this factor are characterised by their very wide span, with the most positive and the most negative attributes registering fairly highly. Servicescape, reputation, credibility and image are seen as the major hindrances to increasing market share while attitude and behaviour are seen as the company's major driver of success. 
Table 8: Participants loading on Factor 5

\begin{tabular}{l|c}
\hline shareholding companies & \\
\hline management & \\
\hline customer facing employees & \\
\hline support function employees & \\
\hline clients, current - individual researchers & \\
\hline clients, lapsed \& potential - individual researchers & $\mathrm{X}$ \\
\hline specialized research institutions & $\mathrm{X}$ \\
\hline commercial companies engaged in research & \\
\hline
\end{tabular}

This view of the company is held only amongst clients, and in particular lapsed clients who have had negative experiences with the company but good experiences with its employees.

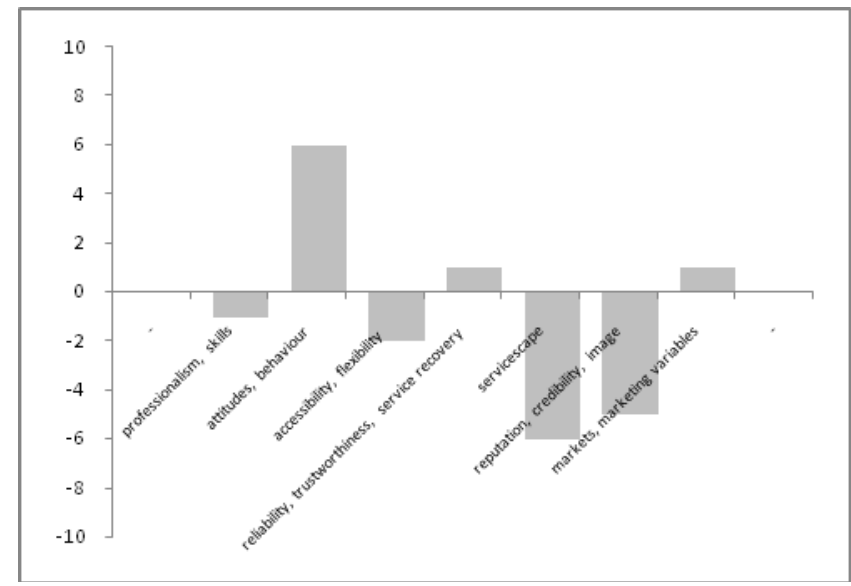

Figure 8: The underlying drivers of consumption in Factor 5

\section{Factor 6: Good employees, poor systems}

Factor 6 represents perception of the company that is best characterised by the title Good Employees, Poor Systems. With 3 percent of the variance and an eigenvalue of 2.72, this factor is a relatively minor but nonetheless coherent perception of the solution meaning of the corporate brand. Employees are perceived to be accessible, with a good attitude, but the company suffers from a poor reputation and offers products and services that don't function particularly well. Significantly, the view that there are no competitive alternatives to the company is part of this perception. The company would therefore be used even if its service quality fell beneath its current level. This point distinguishes the factor from the one that precedes it.

The company's consumption is driven, in the views expressed in this factor, by the attitude of its employees, and inhibited, but to a lesser degree, but the reputation, credibility and image of the company.

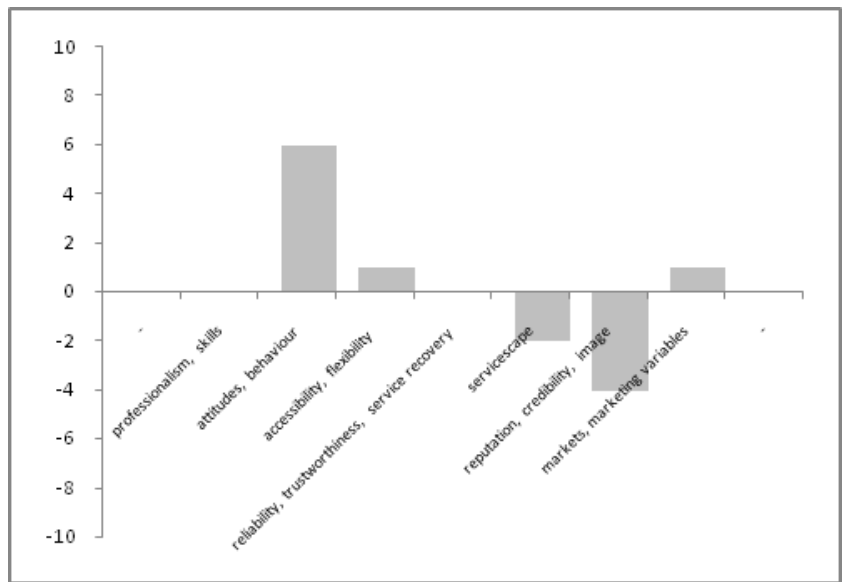

Figure 9: The underlying drivers of consumption in Factor 6

Table 9: Participants loading on Factor 6

\begin{tabular}{l|c}
\hline shareholding companies & \\
\hline management & \\
\hline customer facing employees & \\
\hline support function employees & $\mathrm{X}$ \\
\hline clients, current - individual researchers & \\
\hline clients, lapsed \& potential - individual researchers & \\
\hline specialized research institutions & \\
\hline commercial companies engaged in research & \\
\hline
\end{tabular}

This perception is held only by current clients.

\section{Confounded and insignificant sorts}

A separate assessment of the confounded and insignificant sorts was made, and three primary reasons for their poorly positioned brand perceptions were identified. The company was unknown or insufficiently known amongst many industrial companies and researchers; its products and service processes had undergone continuous change without perceived improvement for a number of years, creating confusion amongst many of its stakeholders; and the company was often confused with its major shareholding companies.

\section{Solution meaning of the corporate brand}

By using $\mathrm{Q}$ methodology, the subjective basis for the utilisation of the company and its financial products and services, and hence the solution meaning (or meanings) of its corporate brand, became evident. Each factor clearly encapsulates specific reasons why the company is or is not used by particular sections of its market, and gives clarity to the foundations of these perceptions within the company and in the market. It is evident that the company is sustained by exceptionally positive perceptions amongst certain of its stakeholders (Factors 1 and 3); that some perceptions of the company contribute very strongly to its rejection (Factor 2); and that some perceptions are mixed (Factors 4, 5 and 6). These factors, with the information gleaned from the confounded and insignificant sorts, offer the company an insight into the unique, subjective perspective of the research participants on the value to them of the company as 
a whole. This formulation of the value of the company is framed from the perspective of its stakeholders, not the company, and offers a very clear assessment of the market orientation of the company. As such, it offers the parameters for strategic development at corporate, marketing or integrated marketing communication levels that address market and stakeholder needs, are zero-based and fundamentally market focused. The findings may also be used as the qualitative foundation of a quantitative study into the reasons for the use or rejection of the company by the market, in which the insights gained, can be tested across the broad population.

\section{Conclusion}

This article explores Q methodology and its utilisation in an area of business research in which subjectivity is of central importance. The subjective perceptions that contribute to the use or rejection of corporate brands are modelled and defined as the 'solution meaning of the corporate brand'. The concept is operationalised and applied in a case study that uses Q methodology to identify key factors that drive consumption or rejection of the corporate brand.

This study proposes theoretical and methodological frameworks for enquiry into the subjectivity that determines the consumption of corporate brands. Two aspects of the work require more attention. The concept solution meaning is preparatory and should be reviewed, expanded and refined. Secondly, the assignment of value to underlying theoretical constructs (the 'underlying drivers of consumption' in the factors of this study) should be reconsidered. In this study values were assigned to underlying constructs only on the basis of their relative positions in the -5 to +5 columns of the factor arrays, and alternative methods for the calculation of these constructs' values should be explored.

\section{References}

Abdullah, F. 2006. 'Measuring service quality in higher education: three instruments compared', International Journal of Research and Method in Education, 29(1):71-89.

Albanese, P.J. 1993. 'Personality and consumer behaviour: An operational approach', European Journal of Marketing, 27(8):28-37.

Andreassen, T.W. \& Lanseng, E. 1997. 'The principal’s and agents' contribution to customer loyalty within an integrated service distribution channel: An external perspective', European Journal of Marketing, 31(7):487-503.

Balmer, J.M.T. \& Greyser, S.A. 2006. 'Corporate marketing: Integrating corporate identity, corporate branding, corporate communications, corporate image and corporate reputation', European Journal of Marketing, 40(7/8):730-741.

Bernstein, D. 1986. Company image and reality: A critique of corporate communications. Eastbourne: Holt, Rinehart \& Winston.
Bitner, M.J. 1992. 'Servicescapes: the impact of physical surroundings on customers and employees', Journal of Marketing, 56(2):57-71.

Black, L.D. \& Härtel, C.E.J. 2002. 'Public relations orientation: Development, empirical testing and implications for managers', Journal of Communication Management, 7(2):117-128.

Bojanic, D.C. \& Rosen, D.L. 1994. 'Measuring service quality in restaurants: an application of the SERVQUAL instrument', Hospitality Research Journal, 18(1):3-14.

Borden, N.H. 1964. 'The Concept of the Marketing Mix', Journal of Advertising Research, 4(2):2-7.

Brady, M.K. \& Cronin, J.J. 2001. 'Customer orientation: effects on customer service perceptions and outcome behaviors', Journal of Service Research, 3(3):241-251.

Brown, S.R. 1980. Political subjectivity: Applications of $Q$ methodology in political science. New Haven: Yale University Press.

Brown, S.R. 1996. 'Q methodology and qualitative research’, Qualitative Health Research, 6(4):561-567.

Buzzell, R.D. \& Gale, B.T. 1987. The PIMS principles: Linking strategy to performance. New York: The Free Press.

Caceres, R.C. \& Paparoidamis, N.G. 2007. 'Service quality, relationship satisfaction, trust, commitment and business-tobusiness loyalty', European Journal of Marketing, 41(7/8):836-867.

Carman, J.M. 1990. 'Consumer perceptions of service quality: an assessment of the SERVQUAL dimensions', Journal of Retailing, 66(1):33-55.

Cronin, J.J. \& Taylor, S.A. 1992. 'Measuring service quality: a reexamination and extension', Journal of Marketing, 56(3):55-68.

Crosby, L.A., Grönroos, C. \& Johnson, S.L. 2002. 'Who moved my value?', Marketing Management, 11(5):10-11.

Cross, R.M. 2005. 'Exploring attitudes: the case for Q methodology', Health Education Research, 20(2):206-213.

Davies, G., Chun, R., da Silva, R.V. \& Roper, S. 2001. 'The personification metaphor as a measurement approach for corporate reputation', Corporate Reputation Review, 4(2):113-127.

Diamond, W. \& Oppenheim, M.R. 2004. 'Introduction to sources and strategies for research on marketing', Journal of Business \& Finance Librarianship, 9(2/3):3-37.

Du Plessis, C., Angelopulo, G. \& Du Plessis, D. 2006. 'A conceptual framework of corporate online communication: a marketing public relations (MPR) perspective', Communicatio, 32(2):241-263. 
Duncan, T. 2002. IMC: Using advertising and promotion to build brands. Boston: McGraw-Hill Irwin.

Duncan, T. \& Moriarty, S. 1997. Driving brand value. New York: McGraw-Hill.

Grönroos, C. 1997. 'Keynote paper: From marketing mix to relationship marketing - towards a paradigm shift in marketing', Management Decision, 35(4):322-339.

Grönroos, C. 2000. Service management and marketing. A customer relationship management approach. $2^{\text {nd }}$ Edition. Chichester: John Wiley \& Sons.

Grönroos, C. 2007. Service management and marketing. Customer management in service competition. $3^{\text {rd }}$ Edition. Chichester: John Wiley \& Sons.

Harris, T.L. 1998. Integrated marketing public relations. In Gronstedt, A. \& Siracuse, L. (Eds.). The ABC's of IMC. New York: Advertising Research Foundation.

Hsieh, A., Chou, C., and Chen, C. 2002. 'Job standardization and service quality: a closer look at the application of total quality management to the public sector', Total Quality Management, 13(7):899-912.

Kapferer, J. 1997. Strategic brand management: Creating and sustaining brand equity long term. London: Kogan Page.

Keller, K.L. 2001. 'Building customer-based brand equity', Marketing Management, 10(2):14-19.

Keller, K.L. 2003. Strategic brand management: Building, measuring and managing brand equity. $2^{\text {nd }}$ Edition. Englewood Cliffs: Prentice-Hall.

Kennedy, S.H. 1977. 'Nurturing corporate images: total communication or ego trip', European Journal of Marketing, 11(3):119-164.

Kidder, L.H. \& Judd, C.M. 1986. Research methods in social relations. $5^{\text {th }}$ Edition. New York: CBS College Publishing.

Kitzinger, C. 1987. The social construction of lesbianism. Bristol: Sage.

Kleine, S.S. \& Baker, S.M. 2004. 'An integrative review of material possession attachment', Academy of Marketing Science Review, 2004(1):1-35.

Kuhn, K.L., Alpert, F. \& Pope, N.K.L. 2008. 'An application of Keller's brand equity model in a B2B context', Qualitative Market Research: An International Journal, 11(1):40-58.

Law, A.K.Y., Hui, Y.V. \& Zhao, X. 2004. 'Modeling repurchase frequency and customer satisfaction for fast food outlets', The International Journal of Quality and Reliability Management, 21(4/5):545-563.
LeBlanc, G. \& Nguyen, N. 1998. 'The mediating role of corporate image on customers retention decisions: an investigation in financial services', International Journal of Bank Marketing, 16(2/3):52-65.

Lee, M. \& Ulgado, F.M. 1997. 'Customer evaluation of fastfood services: a cross-national comparison', The Journal of Services Marketing, 11(1):39-52.

Martin, W.S. \& Reynolds, F.D. 1976. 'On the usefulness of Q-methodology for consumer segmentation', Journal of the Academy of Marketing Science, 4(1):440-445.

McCarthy, E.J. 1960. Basic marketing: A managerial approach. Homewood: Irwin.

McDonald, M.H.B., de Chernatony, L. \& Harris, F. 2001. 'Corporate marketing and service brands - moving beyond the fast-moving consumer goods model', European Journal of Marketing, 35(3/4):335-352.

McEnally, M.R. \& de Chernatony, L. 1999. 'The evolving nature of branding: consumer and managerial considerations', Academy of Marketing Science Review, 1999(2):1-26.

McKeown, B. \& Thomas, D. 1988. Q Methodology. Newbury Park: Sage.

Papasolomou, I. \& Vrontis, D. 2006. 'Using internal marketing to ignite the corporate brand: The case of the UK retail bank industry', Brand Management, 14(1/2):177-195.

Parasuraman, A., Berry, L.L. \& Zeithaml, V.A. 1991. 'Customer-based performance measure: an empirical examination of organizational barriers using an extended service quality model', Human Resource Management, 30(3):335-364.

Popovich, K. \& Popovich, M. 2000. 'Use of Q methodology for hospital strategic planning: A case study', Journal of Healthcare Management, 45(6):405-414.

Porter, M.E. 1980. Competitive strategy: Techniques for analyzing industries and competitors. New York: Free Press.

Porter, M.E. 1985. Competitive advantage: Creating and sustaining superior performance. New York: Free Press.

Ravald, A. \& Grönroos, C. 1996. 'The value concept and relationship marketing', European Journal of Marketing, 30(2):19-30.

Rosenbaum, M.S., Ostrom, A.L. \& Kuntze, R. 2005. 'Loyalty programs and a sense of community', The Journal of Services Marketing, 19(4):222-233.

Scherer, F.M. 1980. Industrial market structure and economic performance. Chicago: Rand McNally College Publishing. 
Schmolck, P. 2008. Correspondence with the author, 18 November 2008.

Schultz, M. \& Ervolder, L. 1998. 'Culture, identity and image consultancy: crossing boundaries between management, advertising, public relations and design', Corporate Reputation Review, 2(1):29-50.

Stainton Rogers, R. 1995. Q methodology. In Smith, J.A., Harre, R. \& Van Longenhove, I. (Eds.). Rethinking methods in psychology. London: Sage.

Spears, N., Brown, T.J. \& Dacin, P.A. 2006. 'Assessing the corporate brand: The Unique Corporate Association Valence (UCAV) approach', Brand Management, 14(1/2):5-19.

Steelman, T.A. \& Maguire, L.A. 1999. 'Understanding participant perspectives: Q-methodology in national forest management', Journal of Policy Analysis and Management, 18(3):361-378.

Stephenson, W. 1935a. 'Technique of factor analysis', Nature. 136(3434):297.

Stephenson, W. 1935b. 'Correlating persons instead of tests’, Journal of Personality. 4(1):17-24.

Stephenson, W. 1953. The study of behavior. Chicago: The University of Chicago Press.

Stricklin, M. \& Almeida, R. 2004. PCQ User's Guide. [online]

URL: http://www.pcqsoft.com/getting htm [7 January 2008].

Uggla, H. 2006. 'The corporate brand association base', European Journal of Marketing, 40(7/8):785-802.

Watts, S. \& Stenner, P. 2005. 'Doing Q methodology: theory, method and interpretation', Qualitative Research in Psychology, 2(1):67-92.

Wei, Y. 2002. 'Corporate image as collective ethos: a poststructuralist approach', Corporate Communications, 7(4):269-276.

Wright, C.M., Riggle, C.G. \& Wright, B.G. 1998. 'Technique for pre-implementation assessment in total quality programs', International Journal of Quality \& Reliability Management, 15(4):414-430.

Zeithaml, V.A., Berry, L.L. \& Parasuraman, A. 1988. 'Communication and control processes in the delivery of service quality’, Journal of Marketing, 52(2):35-48.

Zsóka, A.N. 2007. 'The role of organisational culture in the environmental awareness of companies', Journal for East European Management Studies, 12(2):109-131. 
